\title{
Introduction to the special virtual issue on climate change
}

\author{
N. J. Enright
}

Received: 19 November 2013/Accepted: 20 November 2013/Published online: 27 November 2013

(C) Springer Science+Business Media Dordrecht 2013

This special virtual issue of Plant Ecology draws together 14 papers on climate change published in the journal over the past 5 years. It encompasses a range of ecosystems and species, and issues relating to potential climate change effects on plants and plant communities. The potential impacts of global climate change on the distribution of species, and the distribution, structure and function of communities in the 21 st century have been the subject of an everincreasing scientific literature over the past two decades (Parry 2007). Recent global analyses show that anthropogenic climate change is already affecting species and ecosystems and will continue to do so, with changes in the phenology, distribution and abundance of plants and animals reported for marine, freshwater and terrestrial plants and animals. Measured changes are heavily biased in the directions predicted under global warming scenarios and include earlier timing of spring events such as flowering, bud burst and egg laying, and latitudinal and altitudinal shifts in species ranges (Parmesan 2006). The magnitude and rate of on-going climate change, combined with other stressors, may exceed the adaptive capacity of species and resilience of ecosystems. In addition, changing climate combined with current, and future altered, disturbance regimes may lead to exacerbated

N. J. Enright ( $\square)$

Murdoch University School of Veterinary and Life

Sciences, Murdoch, Australia

e-mail: N.Enright@murdoch.edu.au rates of range contraction and extinction in plant species unable to maintain contact with suitable habitat through dispersal (Westerling et al. 2011; Moritz et al. 2012). Changes to ecosystems may include impoverished species mixes, simplified ecosystem structure and function, and greater vulnerability to invasive species (Malcolm et al. 2006; Midgley and Thuiller 2007; Keeley and Brennan 2012).

Three key conclusions from the 2007 International Panel on Climate Change (Parry 2007) highlight the threat that anthropogenic climate change poses for global plant biodiversity: (1) Resilience of many ecosystems is likely to be exceeded by the combination of climate change, associated disturbances (e.g. wildfire) and other global change drivers. (2) Increases in global temperature of more than $1.5-2.5^{\circ} \mathrm{C}$ and rising atmospheric $\mathrm{CO}_{2}$ concentrations are projected to cause major changes in ecosystem structure, function and species interactions. (3) $2-30 \%$ of plant species globally are at increased risk of extinction.

Many studies on the potential impacts of climate change on plant and animal species have used bioclimatic envelope models which predict the future distribution of species using the correlation of their present range to present-day climate parameters, and the future geographic distribution of these climates based on a range of possible climate futures as described in various GCMs (e.g. Thuiller et al. 2005). Pearson and Dawson (2003) have highlighted the shortcomings of this approach as it ignores factors 
such as biotic interactions, habitat fragmentation, evolutionary change and dispersal ability-and the predictions of such models are difficult to validate (Araújo et al. 2005). Most importantly, it provides no mechanistic understanding of the environmental, ecophysiological and demographic factors that drive species responses. The papers collected in this virtual issue address climate change based on empirical and experimental evidence. They include studies on the plant ecological effects of changes in temperature and rainfall (especially drought), on latitudinal and altitudinal ranges (including effects on snowbeds and treelines), on refugia, seedling establishment, phenology, competition and alien species, and on both individual species and community level responses.

Plant species will respond to climate change in one of three possible ways; migrate to keep pace with climate change (but limited by habitat fragmentation, dispersal ability and substrate requirements), adapt in situ through selection of tolerance traits, or go extinct (Aitken et al. 2008). It is imperative that research continues to explore the potential impacts on plant species and communities of global warming, including interactions with other global change drivers such as shifting disturbance regimes. Such research also needs to address the potential effects of altered frequency and intensity of climate driven events in addition to changing mean conditions and this will be the subject of a forthcoming special thematic issue of Plant Ecology.

\section{References}

Aitken SN, Yeaman S, Holliday JA, Wang T, Curtis-McLane S (2008) Adaptation, migration or extirpation: climate change outcomes for tree populations. Evol Appl 1:95-111

Araújo MB, Pearson RG, Thuiller W, Erhard M (2005) Validation of species-climate impact models under climate change. Glob Change Biol 11:1504-1513

Keeley JE, Brennan TJ (2012) Fire-driven alien invasion in a fire-adapted ecosystem. Oecologia 169:1043-1052

Malcolm JR, Liu C, Neilson RP, Hansen L, Hannah L (2006) Global warming and extinctions of endemic species from biodiversity hotspots. Conserv Biol 20:538-548

Midgley GF, Thuiller W (2007) Potential vulnerability of Namaqualand plant diversity to anthropogenic climate change. J Arid Environ 70:615-628

Moritz MA, Parisien MA, Batllori E, Krawchuk MA, Van Dorn J, Ganz DJ, Hayhoe K (2012) Climate change and disruptions to global fire activity. Ecosphere 3:art49

Parmesan C (2006) Ecological and evolutionary responses to recent climate change. Ann Rev Ecol Evol Syst 37:637-669

Parry, M. L. (Ed.). (2007). Climate Change 2007: Impacts, Adaptation and Vulnerability: Working Group II Contribution to the Fourth Assessment Report of the IPCC Intergovernmental Panel on Climate Change (Vol. 4). Cambridge University Press

Pearson RG, Dawson TP (2003) Predicting the impacts of climate change on the distribution of species: are bioclimate envelope models useful? Glob Ecol Biogeogr 12:361-371

Thuiller W, Lavorel S, Araujo MT, Sykes MT, Prentice IC (2005) Climate change threats to plant diversity in Europe. Proc Natl Acad Sci USA 102:8245-8250

Westerling AL, Turner MG, Smithwick EAH, Romme WH, Ryan MG (2011) Continued warming could transform Greater Yellowstone fire regimes by mid-21st century. Proc Natl Acad Sci 108:13165-13170 